\title{
Studies on Productivity and Performance of Spring Sugarcane Sown in Different Planting Configurations
}

\author{
Samiullah1*, Ehsanullah1, Shakeel Ahmad Anjum1, Mohsin Raza², Naveed Hussain3, \\ Mubashar Nadeem', Nawazish Ali $^{3}$ \\ ${ }^{1}$ Department of Agronomy, University of Agriculture, Faisalabad, Pakistan \\ ${ }^{2}$ Institute of Soil and Environmental Sciences, University of Agriculture, Faisalabad, Pakistan \\ ${ }^{3}$ Department of Agriculture and Food Sciences, Karakoram International University, Gilgit, Pakistan \\ Email: "samisheen14@gmail.com
}

Received 5 August 2015; accepted 30 November 2015; published 3 December 2015

Copyright (C) 2015 by authors and Scientific Research Publishing Inc.

This work is licensed under the Creative Commons Attribution International License (CC BY).

http://creativecommons.org/licenses/by/4.0/

(c) (i) Open Access

\section{Abstract}

Row spacing has a pivotal role in enhancing sugarcane yield and improving its quality. A study was undertaken to evaluate the influence of different planting techniques on performance of sugarcane at Agronomic Research Area, Department of Agronomy, University of Agriculture Faisalabad during Kharif 2014. Experimental treatments comprised of: $180 \mathrm{~cm}$ spaced trenches with tripple row strips, $180 \mathrm{~cm}$ spaced trenches with alternate row strips, $120 \mathrm{~cm}$ spaced trenches with double row strips and $60 \mathrm{~cm}$ spaced furrows with single rows. Sugarcane cultivar HSF-240 was used as experimental material. The experimental was conducted in RCBD with four replications. The expeimental results revealed that sugarcane number of tillers, plant height, cane length, stripped cane weight and stripped cane yield increased progressively with the increase in row spacing from 60 to $180 \mathrm{~cm}$. While germination percentage and number of millable canes were not affected by different sowing techniques, maximum number of tillers $\left(15.96 \mathrm{~m}^{-2}\right)$, plant height $(333.25 \mathrm{~cm})$, stripped cane weight $(0.94 \mathrm{~kg})$ and stripped cane yield $\left(107 \mathrm{t} \cdot \mathrm{ha}^{-1}\right)$ were recorded from $180 \mathrm{~cm}$ spaced trenches with tripple row strips.

\section{Keywords}

Row Spacing, Trench Planting, Furrow Planting, Sugarcane, Yield

\footnotetext{
${ }^{*}$ Corresponding author.
}

How to cite this paper: Samiullah, Ehsanullah, Anjum, S.A., Raza, M., Hussain, N., Nadeem, M. and Ali, N. (2015) Studies on Productivity and Performance of Spring Sugarcane Sown in Different Planting Configurations. American Journal of Plant Sciences, 6, 2984-2988. http://dx.doi.org/10.4236/ajps.2015.619293 


\section{Introduction}

Sugarcane (Saccharum officinarum L.) is a complex hybrid of Saccharum spp. It is a tropical plant but now it is also cultivated widely over the sub-tropics from $30^{\circ}$ north to $35^{\circ}$ south [1]. Sugarcane is important commercial crop of Pakistan after cotton and rice. It plays a marked role in the economic uplift of the growers and the country by mobilizing rural resources and ultimately generates higher revenue and employment opportunities. Sugarcane contributes 3.4 percent in agriculture value addition and 0.7 percent in GDP [2].

There are several reasons for low yield of sugarcane and low sucrose recovery from the cane i.e. Pakistan lies outside of the tropical zone in which sugarcane thrives best. About two-third of the sugarcane area remains in the northern areas where frost is prevalent in winter [1]. In Pakistan, various planting methods have been adopted for maximizing sugarcane yield. Conventionally, sugarcane is planted in 60 to $75 \mathrm{~cm}$ spaced rows which increases plant population per unit area but hinders several management practices necessary for better crop husbandry, which resulted in lodging and hence yield is considerably reduced [3].

Trench planting can play a role in enhancement of cane yield moreover trench planting has significant role in establishing plant population. Planting cane in trenches at row spacing one meter improved juice quality than narrow row spacings [4]. Trench planting is suitable planting technique provides $20 \%$ saving of irrigation water and prevents lodging and provides easiness in earthing-up and inter-culture operations [4]. It was elucidated that sugarcane sown in $120 \mathrm{~cm}$ spaced trenches ameliorated 30\% yield than $60 \mathrm{~cm}$ spaced furrows, with facility of aeration, interculture, preserving irrigation water, weed control, easier fertilizer application and prevents lodging [5].

The proper planting technique of sugarcane is pre-requisite to enable the crop plants to fully utilize environmental conditions to show their optimum potential. Therefore, it is imperative to formulate such planting method which helps in facilitating light penetration, establishing proper plant population, water saving, air circulation, inter tillage and lodging. Therefore, keeping in view the above discussion, the present study was planned with null hypothesis to evaluate the yield and quality of sugarcane under different spacings/planting configurations.

\section{Material and Methods}

The present study was conducted during 2014-2015 at Agronomic Research Area, University of Agriculture Faisalabad, Pakistan. Faisalabad is situated on $31.41^{\circ} \mathrm{N}$ and $73.07^{\circ} \mathrm{E}$. The altitude of Faisalabad is $184 \mathrm{~m}$ above sea level. The soil of the district, Faisalabad, is alluvial plain formed by the rivers: Chenab and Ravi. The summer season starts from April and continues till October while May, June, and July are the hottest months of the year. The mean maximum and minimum temperature in summer are $39^{\circ} \mathrm{C}$ and $27^{\circ} \mathrm{C}$, respectively. Experiment was laid out in Randomized Complete Block Design (RCBD) having four replications maintaining net plot sizes $3.60 \times 6.50 \mathrm{~m}$ for all treatments. Sugarcane was planted under various planting configuration; $180 \mathrm{~cm}$ spaced trenches with tripple row strips, $180 \mathrm{~cm}$ spaced trenches with alternate row strips, $120 \mathrm{~cm}$ spaced trenches with double row strips and $60 \mathrm{~cm}$ spaced furrows with single rows. All other agronomic practices were kept uniform for all treatments. Observations regarding yield and quality related parameters of sugarcane were recorded according to standard procedures. The data recorded were analyzed statistically using Fisher's analysis of variance technique and differences among treatments means were compared using least significant difference (LSD) test at $5 \%$ probability level.

\subsection{Procedures and Formulae for Recording Observations}

\subsubsection{Germination Percentage}

The germination count was recorded 40 days after sowing. Setts, having known number of buds were used per unit area. At completion of germination (40 days after sowing), seedling number was counted and germination percentage was calculated.

\subsubsection{Total Number of Tillers}

Total number of tillers in each plot was recorded and then converted into per square meter by the following formula:

$$
\text { Total tillers }\left(\mathrm{m}^{-2}\right)=\frac{\text { Total number of tillers per plot }}{\text { Plot size }}
$$




\subsubsection{Number of Millable Canes}

Millable canes refer to the canes that-have attained normal height and thickness at their physiological maturity and are ready to harvest for processing. Number of millable canes in each experimental unit was counted at harvest and then converted into number of millable canes per $\mathrm{m}^{2}$.

\subsubsection{Plant Height}

Stalk length of ten canes randomly selected was measured $(\mathrm{cm})$ from bottom to apices at the time of harvest and then averaged.

\subsubsection{Stripped Cane Weight}

A stripped cane refers to the stalk that is clean and free from trash and tops. Ten randomly selected stripped canes from each experimental unit were weighed together and then averaged.

\subsubsection{Stripped Cane Yield}

A stripped cane refers to the stalk that is clean and free from trash and tops. Ten randomly selected stripped canes from each experimental unit were weighed together and then averaged.

\section{Results and Discussions}

\subsection{Germination Percentage}

Good germination means good start which provides the basis for good crop yield. Germination in sugarcane is influenced by different internal and external factors which include sufficient moisture, optimum temperature, proper aeration, good quality seed, type and health of soil [6]. The data on germination percentage Table 1 indicated that different planting techniques did not affect germination percentage significantly which on the average ranged from (44.52\% to $46.15 \%)$. Non-significant difference among all treatments was due to the use of same seed rate for all the treatments and might be due to the fact that there is no competition for light, water and nutrients during germination and there was sufficient space for germination. These findings were in agreement with those of [7] and [8]. They reported minor but non-significant difference in germination of sugarcane.

\subsection{Number of Tillers}

Plant density per unit area has a key role in sugarcane production and tillering is base of establishing a desired crop stand. It is evident from the results presented in Table 1 that tillering was affected by different planting techniques. Sugarcane planted at $180 \mathrm{~cm}$ spaced trenches produced higher number of tillers per square meter (15.96). The spacing of $120 \mathrm{~cm}$ spaced trenches with double row strips and $180 \mathrm{~cm}$ spaced trenches with alternate row strips and were statistically at par with each other 14.33 and 14.02. Lowest number of tillers per meter square 12.66 were recorded from $60 \mathrm{~cm}$ spaced furrow with single row. These results are also in agreement with those of [9] and [10] who reported significantly more number of tillers per unit area in wider row spacing than narrow row spacing in different sowing techniques.

Table 1. Effect of different planting configurations on productivity and performance of sugarcane.

\begin{tabular}{ccccccc}
\hline Treatments & Germination \% & $\begin{array}{c}\text { Number of } \\
\text { tillers }\left(\mathrm{m}^{-2}\right)\end{array}$ & $\begin{array}{c}\text { Millable canes } \\
\left(\mathrm{m}^{-2}\right)\end{array}$ & $\begin{array}{c}\text { Plant height } \\
(\mathrm{cm})\end{array}$ & $\begin{array}{c}\text { Stripped cane } \\
\text { weight }(\mathrm{kg})\end{array}$ & $\begin{array}{c}\text { Stripped cane } \\
\text { yield }\left(\mathrm{t} \cdot \mathrm{ha}^{-1}\right)\end{array}$ \\
\hline $\begin{array}{c}180 \mathrm{~cm} \text { spaced trenches } \\
\text { with triple row strips }\end{array}$ & 46.15 & $15.96 \mathrm{~A}$ & 12.80 & $333.25 \mathrm{~A}$ & $0.94 \mathrm{~A}$ & $107 \mathrm{~A}$ \\
$\begin{array}{c}180 \mathrm{~cm} \text { spaced trenches } \\
\text { with alternate row strips }\end{array}$ & 45.42 & $14.02 \mathrm{~B}$ & 12.02 & $317.75 \mathrm{C}$ & $0.85 \mathrm{C}$ & $99 \mathrm{C}$ \\
$\begin{array}{l}120 \mathrm{~cm} \text { spaced trenches } \\
\text { with double row strips }\end{array}$ & 45.75 & $14.33 \mathrm{~B}$ & 12.30 & $325.25 \mathrm{~B}$ & $0.89 \mathrm{~B}$ & $102.25 \mathrm{~B}$ \\
$\begin{array}{c}60 \text { cm spaced furrows } \\
\text { with single row }\end{array}$ & 44.52 & $12.66 \mathrm{C}$ & 11.12 & $311.25 \mathrm{D}$ & $0.80 \mathrm{D}$ & $91 \mathrm{D}$ \\
\begin{tabular}{l} 
LSD at $0.05 \%$ \\
\hline
\end{tabular} & NS & 0.82 & NS & 6.34 & 2.33 & 1.36 \\
\hline
\end{tabular}




\subsection{Plant Height}

Plant height in sugarcane is the combination of crop growing conditions and varietal character. Plant height also plays very important role in determining the final cane yield. Data regarding the effect of different planting configurations on plant height revealed that plant height was significantly affected by different planting pattern presented in Table 1. Statistically maximum plant height $333.25 \mathrm{~cm}$ was obtained in crop planted at $180 \mathrm{~cm}$ spaced trenches with triple row strips. Crop planted at $120 \mathrm{~cm}$ spaced trenches with double row strips produced plant height of $325.25 \mathrm{~cm}$ followed by $180 \mathrm{~cm}$ spaced trenches with alternate row strips $317.75 \mathrm{~cm}$. Plants with lower plant height were produced in $60 \mathrm{~cm}$ spaced furrow with single row $311 \mathrm{~cm}$.

More plant height in $180 \mathrm{~cm}$ spaced trenches with tripple row strips might be due better utilization of nutrients and water, better light penetration into the crop canopy, enhanced photosynthesis rate due to better light penetration and cross-air circulation because of wider spacing, sufficient distance between setts. The higher plant height also might be attributed to availability of better growth conditions that resulted in increased leaf area index and intercepted more radiation that finally produced taller plants. Moreover, there might be less interplant competition for water and nutrients, due to greater seed-bed depth and localized application of water and nutrients, which ultimately resulted in taller plants. While less plant height in case of $180 \mathrm{~cm}$ spaced trenches with alternate row strips might be due to less utilization of nutrients and water, less space because of dense plant population. Less plant height in $60 \mathrm{~cm}$ spaced furrow with single row strips might be due to less light penetration into the crop canopy and cross-air circulation because of lower spacing. Similar results were reported by [11]-[13].

\subsection{Stripped Cane Weight}

Data regarding weight per stripped cane Table 1 indicated that there were significant differences for weight per stripped cane among the treatments. Statistically weight per stripped cane recorded for $180 \mathrm{~cm}$ spaced trenches with triple row strips was maximum $(0.92 \mathrm{~kg})$. Weight per stripped cane recorded for $120 \mathrm{~cm}$ spaced trenches with double row strips was $(0.91 \mathrm{~kg})$ which was statistically at par with $180 \mathrm{~cm}$ spaced trenches with alternate row strips $(0.88 \mathrm{~kg})$. Lowest weight per stripped cane $(0.86 \mathrm{~kg})$ was obtained from $60 \mathrm{~cm}$ spaced furrow with single row.

Weight per stripped cane determines the overall yield of the crop and efficiency of the treatments. The individual stripped cane weight is the combined result of many yield contributing components like number of millable canes, cane diameter and cane length and these components were affected by different planting configurations. Thus, final cane weight was also affected by these factors. Thus, final cane weight was also affected by these factors. The results are quite in line with my findings [13].

\subsection{Stripped Cane Yield}

The data regarding stripped cane yield which is presented in Table 1 showed that different planting configurations gave different stripped cane yield. At harvest highest stripped cane yield $107 \mathrm{t} \cdot \mathrm{ha}^{-1}$ was noted from $180 \mathrm{~cm}$ spaced trenches with triple row strips. Sugarcane planted at $120 \mathrm{~cm}$ spaced trenches produced stripped cane yield $102.25 \mathrm{t} \cdot \mathrm{ha}^{-1}$ followed by cane planted at $180 \mathrm{~cm}$ spaced trenches with alternate row strips $99 \mathrm{t} \cdot \mathrm{ha}^{-1}$. Lowest stripped cane yield $91 \mathrm{t} \cdot \mathrm{ha}^{-1}$ at harvest was noted from $60 \mathrm{~cm}$ spaced furrow.

Greater stripped-cane yield in $180 \mathrm{~cm}$ spaced trenches with tripple row strips might be ascribed to higher rate of photosynthesis due to enhanced light interception and less plant mortality. The significant difference in yield might be due to less interplant competition which facilitated aeration, and sunlight availability to the crop plants, which boosted the crop growth rate. A linear increase in stripped cane yield of sugarcane with increase in row spacing has also been reported by [3] [10] and [14].

\section{Conclusion}

Different planting configurations had no significant effect on plant establishment traits like germination percentage and quantitative traits like number of millable canes. Whereas it was significant, for number of tillers, plant height stripped cane weight and stripped cane yield. Highest stripped-cane yield of sugarcane $107 \mathrm{t} \cdot \mathrm{ha}^{-1}$ was noted at $180 \mathrm{~cm}$ spaced trenches with tripple row strips. 


\section{References}

[1] Nazir, M.S. (1994) Sugarcane. Crop Production (Edn; Bashir and Bantel), National Book Foundation, Islamabad, 421422.

[2] Govt. of Pakistan (2014) Pakistan Economic Survey, 2013-14. Ministry of Food Agriculture and Livestock, Federal Bureau of Stat, Islamabad, 27.

[3] Ullah, E., Jabran, M.K. and Ghaffar, A. (2011) Optimizing the Sugarcane Row Spacing and Seeding Density to Improve Its Yield and Quality. Crop and Environment, 2, 1-5.

[4] Chattha, M.U., Ali, A. and Bilal, M. (2007) Influence of Planting Techniques on Growth and Yield of Spring Planted Sugarcane (Saccharum officinarum L.). Pakistan Journal of Agricultural Sciences, 44, 452-456.

[5] Chattha, A.A., Afzal, M. and Chattha, M.U. (2004) Sustainable Cultivation of Sugarcane for Revival of Sugar Industry in Pakistan. Proceedings of the 39th Annual Convention, Pakistan Society of Sugarcane Technologists, 36-49.

[6] Dillewijn, C.V. (1952) Botany of Sugarcane. The Chronica Botanica Co. Book Deptartment, Waltham, 59-151.

[7] Singh, A.K., Lal, M. and Singh, S.N. (2011) Agronomic Performance of New Sugarcane Genotypes under Different Planting Geometries and N Levels. Indian Journal of Sugarcane Technology, 26, 6-9.

[8] Patel, D., Raj, V.C., Tandel, B., Patel, B., Patel, B., Patil, P., Patel, A.M. and Patel, D.U. (2014) Sugarcane Yield and Nutrient Uptake under Plant Geometry and Variety in Relation to Mechanization. The Bioscan, 9, 1445-1448.

[9] Bashir, S., Chattha, A.A., Yasin, M. and Mahmood, Z. (2005) Sugarcane Varieties and Row Spacing Effect on Sugarcane Traits. Pakistan Sugarcane Journal, 20, 18-20.

[10] Zafar, M., Tanveer, A., Cheema, Z.A. and Ashraf, M. (2010) Weed-Crop Competition Effects on Growth and Yield of Sugarcane Planted Using Two Methods. Pakistan Journal of Botany, 42, 815-823.

[11] Ghaffar, A., Ullah, E., Akbar, N. and Khan, S.H. (2011) Influence of Zinc and Iron on Yield and Quality of Sugarcane Planted under Various Trench Spacings. Pakistan Journal of Agricultural Sciences, 48, 25-33.

[12] Garcia, R.E.R., Pineda, R. and Cairo, P. (1989) Influence of Cultivation Depth on the Fall in Cane Yields in Vertisoles. Entro Azuc, 15, 83-89.

[13] Maqsood, M., Iqbal, M. and Tayyab, M. (2005) Comparative Productivity Performance of Sugarcane (Saccharum officinarum L.) Sown in Different Planting Patterns at Farmer’s Field. Pakistan Journal of Agricultural Sciences, 42, 3-4.

[14] Sajjad, M., Bari, A., Nawaz, M. and Iqbal, S. (2014) Effect of Planting Pattern and Nutrient Management on Yield of Spring Planted Sugarcane. Sarhad Journal of Agriculture, 30, 67-71. 